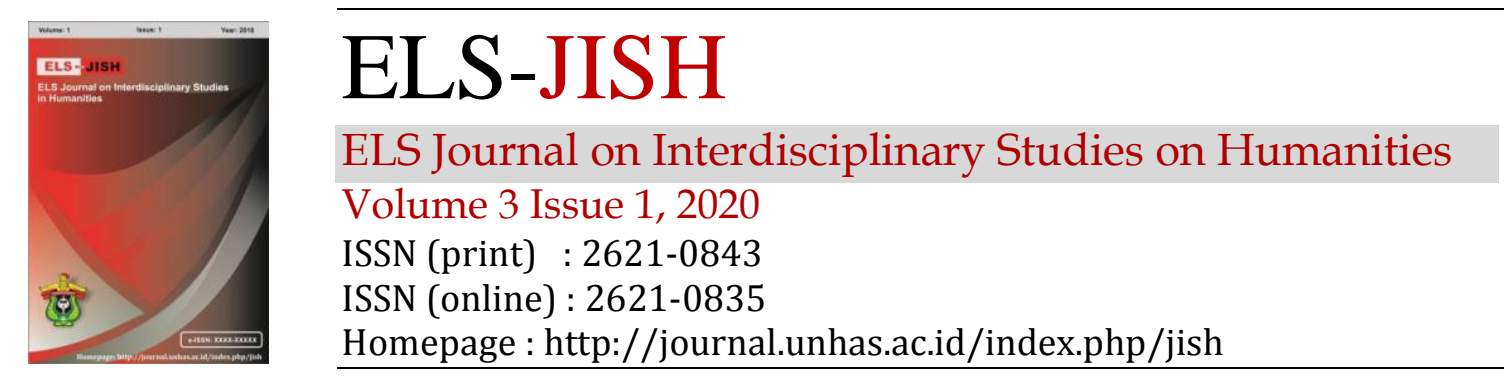

\title{
The Student-Created Poster: A WebQuest Active Learning Strategy in Online Environments
}

\author{
Hilda Rakerda ${ }^{1}$, Nur Arifah Drajati ${ }^{2}$, Ngadiso ${ }^{3}$ \\ 1hld rec11@student.uns.ac.id
}

\begin{abstract}
Posters are one of the school project artifacts that students could create to engage themselves in their knowledge building at school. Combine with WebQuest as the active learning instruction platform in an online learning, creating posters increase students' engagement, build interest in topic learned, inspire higher-level independent thinking, and motivate student on their personal learning experiences. The aim of this study was to investigate student-created poster as an active learning approach in an online environment using WebQuest to inform instructional practices of student-created poster. This study used a case study method to explore the phenomenon occurred during the elective English course in the first grade of senior high school at Indonesia. Data analyzed in this study included 21 high school students, students' posters and the classroom observation done in 5 weeks. The finding of this qualitative study revealed that student-created poster utilizing WebQuest as the instructional learning method was an active learning activity that improve students perception of self-efficacy in comprehend the reading text and write the information in poster and evidence of student engagement of behavioral, affective and cognitive domains. Themes derived from the perception of the participants included: perceived self-efficacy, the novelty or usefulness of creating a poster, and the technical and content knowledge. Student-created poster as an active approach using WebQuest can be included in the context of High School English learning to enhance the English skills of students and foster integrative skills of the 21st century. Practical implications for teachers when designing poster assignments created by students using WebQuest include (a) following a model for the development of posters; (b) providing extra time for content acquisition and revisions; and (c) incorporating group evaluation.
\end{abstract}

Keywords: Student-created Poster, Active Learning, Online Environment and WebQuest.

How to cite: Rakerda, H., et al. (2020). The Student-Created Poster: A WebQuest Active Learning Strategy in Online Environments. ELS Journal on Interdisciplinary Studies in Humanities, 3(1), 75-84. DOI: http://dx.doi.org/10.34050/els-jish.v3i1.9523

\section{Introduction}

As the demand for language education has increased in recent years along with the advancements in technology, teachers are leaded to have a skill and knowledge to integrate technology in combination with appropriate pedagogy to have a positive impact on foreign language (FL) learning (Rienties, 2017). In line with Rienties, Hung (2015) supports that educators in the twentyfirst century are constantly adopting new technologies and pedagogies such as

${ }^{1,2,3}$ Universitas Sebelas Maret, Indonesia. 
providing a students' literacy environments which is highly social, active, and multimodal ( Kuure, 2011). Today, the World Wide Web (WWW) is a major part of our lives (Kurt, 2012) and presents great opportunities for academic life, especially for teachers and students.

The WWW such as WebQuests is often used by teachers for the classroom activities (hung, 2015; Kurt, 2012) which form more specific learning tools within the context of second-language acquisition and foreign language learning. WebQuests is an internet-based module (Dodge, 2001) created by the teacher or material developer to engage students with such open educational resources/open educational practices (Littlejohn \& Hood, 2016; Thomas \& Evans, 2014) and help them develop their knowledge and skills needed to successfully participate in broader social and cultural contexts.

Most educators agree that Webquest as a learning platform supports active learning (Ebadi, 2018; Ewada, 2019; and Hung, 2015) since the ideal educational experience is one in which students are prepared to actively engage in the learning process (Gibbs, 1992) and thinking about the things they are doing (Bonnell and Eison,1991). Conceptually, active learning is an umbrella term to a vast range of learning activities, instructional strategies, teaching methods, and any pedagogical approach that is intended to activate or develop the students' thinking in the learning process (Hung, 2015) that enables students to develop meaning from knowledge (Cook and Babon, 2016).

In Asia, Webquest is widely used by educator as a learning instruction tool to allow the students' autonomy, creativity and higher order thingking (Amalia and Jati, 2018; Hung, 2015; Noordin, Samad and Razali, 2008; Sumarno, Tatik and Shodikin, 2017). Hung (2015) found that the structure of learning materials, augmented by the use of WebQuests, had a positive impact on how university students in Taiwan perceived the learning environment and engaged in the learning process since it builds students independent learning to choose the topic to learn. Amalia and Jati (2018) added that learning English using WebQuest successfully improve self efficacy and higher order thinking in the material learned viewing from the result of the assignments done by the Indonesian university students and their group review. Noordin, Samad and Razali (2008) urge university students in Malaysia to recognize the potential of the WebQuest as a tool that offers opportunities to actively engage in learning by connecting to the Internet and other resources available.

However, research exploring how senior high school students perceive the online environment using WebQuest active learning strategy to created poster especially in English course remind limited. Therefore, this study tries to investigate student-created poster in an active learning online environment related to student knowledge, engagement and self-efficacy in English course. The findings provided implications for educators related to the implementation of student-created poster included perceived content knowledge acquisition and expected to be used by English teachers to engage students in the learning material to support their English learning activities in the classroom and outside the classroom. 


\section{Method}

This paper studies the progress of students during the 5 weeks period of Webquest implementation in poster projects where students need to explore resources by themselves through WebQuest and create poster based on their own chosen topics attached and explained in the WebQuest learning platform. The WebQuest learning platform was used as the substitute of the printed book in the class. This report present a case study investigating how high school students practice the active learning approach using Webquest to create poster as the result of the English learning in elective English course at Indonesian High School. These students chose English course as an elective course in their school in which Webquest as a learning platform to foster active learning was adopted. The elective English course focused on developing students reading comprehension and writing skill. In this respect, the students must demonstrate their ability in comprehend the reading passage attached in the WebQuest and make a poster as a result of their reading. In this elective English course, 21 students ( 7 males and 14 females) of 38 students (13 males and 15 females) in the first grade of senior high school were interviewed to know the students' perception of the lesson done. The students were devided into group consist of 4 or 5 students and each student in the group must write one part of the poster after they had surveyed topic on WebQuest. The Poster was made through power point slide and the total posters collected were 9 posters from 9 groups.

In the lesson during week 1, participants received preliminary information that they would be creating a poster related to advertisement (the material was based on the school syllabus). The participants had to survey the material presented on WebQuest and freely chose the topic based on the topics listed in the WebQuest (the topic about job vacancy advertisement, product advertisement and service advertisement). At the end of week 1, participants completed the pre-survey and indicated the topic of their poster. At the beginning of week 2 , participants received detailed assignment instructions and planning their poster which was include the logo, slogan, illustration, highlight words, information attached in the poster and kind of picture that would they put in the poster. The students also decided the layout for their poster. By the end of week 2, participants were required to complete the logo, the slogan, the highlight, and the information or body copy of the poster. During week 3 , each group introduce the topic, the logo, the slogan, the highlight, information and describe kind of picture they would put in their poster while other groups gave reviewed ideas of their friend group poster planning. The agenda for weeks 4 and 5 involved completing the poster creation using power point slide, review from the teacher, and finalized the poster.

The academic content areas for the student-created poster were English course suitable with the school syllabus. Each poster planning was reviewed by other group for accuracy of content and other required elements. Online reviews were assigned randomly by the teacher through the learning management system. Students agreed to revise the poster if an error was found during the group review or teacher grading process. The posters were required to include elements such as: (a) logo; (b) slogan; (c) highlight; (d) illustration/picture; and 
(e) information. The poster also should follow one of the poster layout explained in the WebQuest. For the purpose of the analysis, the framework used is based on the theory of active learning approach to increasing students' selfefficacy and engagement in higher levels of cognitive skills (Bloom, Engelhart, Furst, Hill, \& Krathwohl, 1956) and is grounded in the theoretical work of Bandura's Social Cognitive Theory (1991) and Papert and Harel's Constructionism Theory (1980; 1991)

\section{Results}

For knowing the students' perception about the process of designing and developing a student-created poster in online learning environment utilizing WebQuest, the researcher conducted semi structure interview to the participants and responses were highlighted to identify participants' beliefs about creating their poster. In this study, learners' perception was analyzed through the words of the participants about the learning experience of designing and creating a poster. Finally, the responses were coded for the emergent themes determined. For knowing how a student created poster assignment effects the students' engagement, an analysis of behavioral activities (completion of activities) were also considered based on the semi structure interview and the classroom observation.

\subsection{The students' perception about the process of designing and developing a student-created poster in online learning environment utilizing WebQuest}

According to Bandura (1997), social modeling, verbal persuasion, and physiological states can foster and strengthen self-efficacy through mastery experiences. Levels of self-efficacy can predict engagement and trust amongst learners. The greater the level of self-efficacy one possesses, the higher their agentic perspective (Bandura, 2008). An agentic individual, one who demonstrates motivation, self-regulation, self-organization, self-reflection, and self-correction, has built up experiences and challenges on their own agency (Bandura, 1986, 1991). The detailed perceptions of the students during the first phase of creating the poster until the end of the lesson are listed below.

\subsubsection{Poster planning phase}

When the teacher first entered the class, the teacher introduced the topic they would learn by using WebQuest. All students were asked to take out their Smartphones and were asked to turn on their internet to access the material they would study on WebQuest. The teacher told the final project the students would be working on and how to do it based on the steps explained on the WebQuest. Then, the students were asked to conduct surveys about the topic for their poster and begin to plan their poster content. To determine students' perceptions in designing posters, participants were asked the relevance of following the direction from the teacher to make an interesting poster. All of the participants responded positively to have a plan before making their poster to produce the qualify poster. Here are some positive expressions from the students.

"As the student, I like to follow the teacher instruction because I don't know what to do so I just follow the instruction" 
"I followed it because I have to follow the teacher to have a good mark from the teacher"

"In my opinion, making a plan make us easier to created the poster, maybe"

\subsubsection{Poster development phase}

Participants expressed their perceptions related to the poster development process. The semi structure interview themes of the participants' perceptions included: (a) self-efficacy, (b) novelty or usefulness, and (c) perceived knowledge (content and technical). Representative comments that were coded for each of these categories provided evidence of students' perceptions of the poster development process (see Table 1). Most students expressed increased self-efficacy in their technological skills, perceived positive novelty of the material learn and learn the content better. Most Participants indicated that they increased their English vocabulary, content and technical knowledge of poster development through the poster creating using power point slide process. However, there were students who indicated the technological aspects of the task were difficult, making the poster was not novelty and they cannot understand the material well by using the poster project

Table 1. Poster development: representative responses from participants.

\begin{tabular}{|c|c|c|}
\hline & Positive & Negative \\
\hline $\begin{array}{l}\text { Self Efficacy with } \\
\text { technology }\end{array}$ & $\begin{array}{l}\text { "In my opinion, learning to use } \\
\text { Webquest is more practical and } \\
\text { can be accessed anywhere. } \\
\text { Maybe it could be an alternative } \\
\text { beside printed book. I and my } \\
\text { group find it easier find the } \\
\text { topic for my poster using } \\
\text { WebQuest since it attached the } \\
\text { steps. Making the poster } \\
\text { through power point is also } \\
\text { easier. I love it." } \\
\text { "WebQuest makes my learning } \\
\text { more fun, because it's more } \\
\text { effective, very interesting and } \\
\text { makes learning easier to } \\
\text { understand, I am enthusiastic } \\
\text { enough to learn and created a } \\
\text { poster. It is easier created } \\
\text { poster in power point. I just } \\
\text { know." } \\
\text { "It is more cheaper to created } \\
\text { poster by using power point } \\
\text { and WebQuest hehe" }\end{array}$ & $\begin{array}{l}\text { "It is difficult if i do not } \\
\text { have an internet access } \\
\text { in my Smartphone } \\
\text { because school Wi-fi is } \\
\text { also restricted in use, } \\
\text { another problem when } \\
\text { using my own internet } \\
\text { access appears because } \\
\text { it is loading to long. So I } \\
\text { often miss the poster } \\
\text { work information." } \\
\text { "I feel it is a little difficult } \\
\text { to created a poster using } \\
\text { power point since we } \\
\text { make it using } \\
\text { smartphone. I prefer } \\
\text { printed material because } \\
\text { the blue light on } \\
\text { Smartphone, it makes my } \\
\text { eyes a bit sore. I feel a } \\
\text { bit confuse to make } \\
\text { poster using power point" }\end{array}$ \\
\hline Nov & $\begin{array}{l}\text { "It is more practical not to bring } \\
\text { books and also the material has } \\
\text { been summarized so no need } \\
\text { to take. Hehe" } \\
\text { "It is fun because it utilizes } \\
\text { appropriate technology that }\end{array}$ & $\begin{array}{l}\text { "Certain part consists of } \\
\text { small picture and unclear } \\
\text { picture, so I just skip it } \\
\text { becauser I don't } \\
\text { understand it. Using } \\
\text { power point to created }\end{array}$ \\
\hline
\end{tabular}




\begin{tabular}{|c|c|c|}
\hline & $\begin{array}{l}\text { must be used in learning so } \\
\text { that learning is fun and does } \\
\text { not seem old-fashioned." } \\
\text { "I think learning media through } \\
\text { WebQuest is innovative } \\
\text { (something new) and efficient } \\
\text { because teachers can get more } \\
\text { extensive and complete } \\
\text { learning material for students" }\end{array}$ & $\begin{array}{l}\text { poster is too hard for me. } \\
\text { I prefer to use my laptop } \\
\text { than use smartphone to } \\
\text { make it" }\end{array}$ \\
\hline $\begin{array}{l}\text { Perceive } \\
\text { Knowledge }\end{array}$ & $\begin{array}{l}\text { "it is one way we can do to } \\
\text { learn English, I think because } \\
\text { word in poster is sometimes } \\
\text { strange. So, I remember it } \\
\text { easily. I got a lot of new } \\
\text { vocabulary in the process. } \\
\text { Hehe" }\end{array}$ & $\begin{array}{l}\text { "Too much text. It hard } \\
\text { for me to understand } \\
\text { which one needed and } \\
\text { not needed. May be, it } \\
\text { need to be replaced with } \\
\text { picture illustrations so I } \\
\text { could find the purpose } \\
\text { easily." }\end{array}$ \\
\hline
\end{tabular}

\subsubsection{Poster feedback phase}

The perceptions of the poster itself included ways in which the group compared each poster plan and gave the comments orally and also in a piece of paper. The comment made in the piece of the paper were given to the group commented. The students were more motivated to investigate the other groups poster plans. Each group presented the poster plan orally and the other group were asked to check the part of the poster whether the poster had complete part of the poster, gave comment about the slogan words, the brand name and the logo. For instance:

"The hardest part in poster project was planning the poster. I didn't understand what I was doing at first, but I eventually got it after the other group presented their planning."

"I enjoyed the process of creating this poster. Editing the poster, sometimes I doubt my group project plan and need the suggestion of the teachers and other group"

\subsection{The students' engagement in creating poster assignment}

For the student-created poster assignment, engagement was categorized into three domains based on Papert and Harel's Constructionism Theory (1980; 1991) that included: (a) behavioral, (b) affective, and (c) cognitive engagement. The data gathered by classroom observation and semi structure interview to know the students' perception. Fredricks et al ( 2004), explained the kinds of activities that included in behavioral, affective, and cognitive engagement. Behavioral engagement indicators for this study included : a) the completion of the assignment; b) group review; c) participation; and d) interaction with peers or others related to the assignment Positive affective engagement encompassed contributing positive attitude, values, interest, curiosity, emotion exhibit when completing the assignment. Cognitive engagement was demonstrated by how strategically the student attempted to learn and create the poster through power point slide. Most of the participants gave positive students' engagement comments. Based on the classroom observation, it was found that all of the students hand in the poster project on time. 
"It is easier for me because I did the project in group, so we hand in the poster on time. Fortunately"

Regarding behavioral engagement, all of the group created a poster, the poster plan and the poster assignments in the class. All of them completing the group reviews and gave the review to the other group for consideration of all elements and contents in the poster. The students' suggestions for other group may not have been considered in the creation of the final artifact. Affective and cognitive engagements were evident throughout the interview statements. For affective engagement domain, most of the students perceived positively the activities done during the poster project. Here are some examples of the statements.
"After seeing other group poster plan, I found that my poster idea still need to be broaden. I got positive suggestion from the other group about the idea of my group poster"
"Firstly, I was afraid that my group idea was not to good but thanks to the other group that gave my group clearer idea"
"I was happy because more learning with Webquest was more interesting and printed book and I feel, created poster through power point were arousing my interest in learning"

Most of the participant gave positive cognitive engagement comment about the how strategically the student attempted to learn and create the poster through power point slide. Here are some of the statements examples.

\begin{abstract}
"I and my friends got confuse how to make a poster using power point before because we know that to make a poster we need to open our computer and use sophisticated editing application. Then after we saw the video attached in the WebQuest, we just know that power point slide was so simple and could be use in poster creation using smartphone."

"Firstly, we doubt that we could make poster using power point. After having discussion with the teacher and saw the video about how to make poster in power point slide on WebQuest, we understand how to edited. We make a bit simple poster using power point than if we use photoshop"
\end{abstract}

\title{
4.Discussion
}

In this study, data relative to student-created poster in English course were analyzed for evidence of active learning, self-efficacy, and student engagement to inform teaching and learning in elective English course. In line with Harel and Papert's (1990) theory that students learn through thinking and doing, the perceptions of students and the creation of a poster confirmed that the poster created by the students contributed to the perceived knowledge of the participants. The participants perceived that they gained a in-depth understanding about English content along the process of studying the material using WebQuest, designing/planning the poster and editing poster using power point slide. They increase their vocabulary, creativity and technological knowledge when they edited the poster using power point slide. Each member in the group were also responsible to their division material (affective engagement) to ensure the information they were conveying was accurate, understandable and to make sure the poster project could be finished on time. Students' self-efficacy in English content and in technology skills were improved 
showed from the intention of the students to learn and created a creative and funny poster project. Even though the posters made by the students was so interesting and creative, they also consider the content of the material. The group review donated a lot of suggestion to each group to have qualify poster base on the material. The students completed the part of the poster included logo, slogan, illustration, highlight and the information. The students sill considered the purpose of the lesson. Those who need additional support in the technological aspect of creating poster using power point slide were support from those who master the power point slide creation. They saw the techniques from the video attached in the WebQuest and began to apply it. Once they got problem or difficulties, they come to the teacher to have a solution.

According to the participants in the study, student-created poster was still considered an innovative and enjoyable activity whereas combine with the use of technology. Further, the process of creating the poster using a power point slide and subsequent group reviews were completely novel. Modeling (Bandura, 1997) and practice (Joyce \& Showers, 1980; Guskey, 1986) are essential to encourage future teachers to adopt active learning practices such as poster creation in their future classrooms (Mitchell, Hirn, \& Lewis, 2017). The teacher should introduce the way to finish the project by using video or attach the explanation to complete the assignment so the students could follow the instruction on the right track. For educators, the findings provided implications related to the implementation of studentcreated poster that included issues of perceived content knowledge acquisition enjoyable. Further, planning sufficient time for peer review or group review and revision will benefit the finalized poster product and to lead the poster creation on the right track.

Findings from participant engagement indicated that poster created by students could be considered an activity that contributes to behavioral, affective, and cognitive engagement (Mitra et al., 2010). As evidenced in the interview, the participants felt inspired, motivated, and persistent (affective engagement) while researching and developing more knowledge of content (cognitive involvement). Participants enjoyed the poster development process even when they were troubled some time by the technology. From these findings educators can consider the student-created poster combine with WebQuest as the instructional learning platform as the active learning activities to increase the students knowledge about the English content.

\section{Conclusion}

The student-created poster enabled participants in this study to embrace and grapple with integrative and interdisciplinary of English reading comprehension and writing skill. The study's importance broadens the knowledge base for: (a) student-created Poster assignments conducted in online learning environments, (b) the utilization of a poster development using power point slide, (c) increasing self-efficacy in English skill through active learning, and (d) increasing perceived knowledge through a principle of constructionism promoted by Harel \& Papert (1990). 


\section{References}

Amalia, Dian, \& Jati, Roko Patria. ( 2018). The use of Webquest in blended EFL learning in Indonesia to improve students' speaking skills. Attarbiyah, Volume 28, 2018, pp.1-16 1

Awada, Ghada. Burston, Jack \& Ghannage, Rosie. (2019). Effect of student team achievement division through WebQuest on EFL students and their instructors' perception. Computer Assisted Language Learning.

Bandura, A. (1986). Social foundations of thought and action: A social cognitive theory. Englewood Clif, NJ: Prentice Hall.

Bandura, A. (1991). Social cognitive theory of moral thought and action. In W. M. Kurtines, \& J. L. Gewirtz (Eds.) Hanbook of moral behavior and development (Vol. 1, pp. 45-103). Hillsdale, NJ: Erlbaum.

Bandura, A. (1997). Self-efficacy: The exercise of control. New York: Freeman.

Bandura, A. (2008). Toward an agentic theory of the self. Advances in Self Research, 3, 15-49.

Bonwell, C. C., Eison, J. A. (1991). Active learning: Creating excitement in the classroom. Washington, DC: George Washington University

Campbell, L. O., \& Cox, T. (2018). Digital video as a personalized learning assignment: A qualitative study of students craed video using the ICSDR model. Journal of the Scholarship of Teaching and Learning,18(1),11-24.

Dodge, B. (2001). FOCUS: Five rules for writing a great WebQuest. Learning \& Leading with Technology, 28 (8), 6-9.

Ebadi, Saman \& Rahimi, Masoud. (2018). An exploration into the impact of WebQuest-based classroom on EFL learners' critical thinking and academic writing skills: a mixedmethods study, Computer Assisted Language Learning.

Fredricks, J. A., Blumenfeld, P. C., \& Paris, A. H. (2004). School engagement: Potential of the concept, state of the evidence. Educational Research, 74, 59-109.

Gibbs, G. (1992). Improving the quality of student learning. Bristol: Technical and Educational Services

Ltd.Guskey,T.R.(1986).Sta?developmentandtheprocessofteacherchange.Educa tionalResearcher,15(5),5-12.

Harel, I., \& Papert, S. (1990). Software design as a learning environment. Interactive Learning Environments, 1(1), 1-32.

Hung, Hsiu-Ting. (2015). Flipping the classroom for English language learners to foster active learning, Computer Assisted Language Learning, 28:1, 8196,

Joyce, B., \& Showers, B. (1980). Improving in service training: The messages of research. Educational Leadership, 37 (5), 379-385. 
Littlejohn, A., \& Hood, N. (2016). How educators build knowledge and expand their practice: The case of open education resources: how educators build knowledge and expand their practice. British Journal of Educational Technology, 48(2), 499-510.

Mitchell, B. S., Hirn, R. G., \& Lewis, T. J. (2017). Enhancing ective class room management in schools: Structures for chan ging teacher behavior. Teacher Education and Special Education,40(2), 140-153.

Mitra, B., Lewin- jones, J., Barrett, H., \& Williamson, S. (2010). The use of video to enable deep learning. Research in Post- Compulsory Education, 15(4),405-414.

Noordin, N., Samad, A. A., \& Mohamed Razali, A. B. (2008). ESL TeacherTrainee Reflections On The Use Of The WebQuest: Practical Or Just A Hype? The English Teacher, University Putra Malaysia, XXXVI, 66-80.

Rienties, Bart,. Lewis, Tim,. McFarlane, Ruth,. Nguyen, Quan \& Toetenel, Lisette. (2017). Analytics in online and offline language learning environments: the role of learning design to understand student online engagement, Computer Assisted Language Learning,

Sumarno, Wahyu Kyestiati,. Tatik ,. \& Shodikin, Ali. (2017). Developing Constructivist-Webquests Online Materials for TEFL Course .Journal of English Language, Literature, and Teaching. METATHESIS, Vol. 1, No. 2,

Thomas, M., \& Evans, M. (2014). Guest editorial. Computer Assisted Language Learning, 27(2), 107-108.

Papert, S. (1980). Mindstorms: Children, computers, and powerful ideas. New York: Basic Books, 1980.

Papert, S., \& Harel, I. (1991). Situating constructionism.Constructionism,36 (2), 1-11. 